\title{
Management Control Use and Decisions in Brazilian Health Organizations: an Exploratory Study
}

\author{
José Carlos Tiomatsu Oyadomari ${ }^{\dagger}$ \\ Mackenzie Presbyterian University
}

Alexandre de Lacerda Pedrique ${ }^{\Omega}$

Mackenzie Presbyterian University

\author{
Diógenes de Souza Bido ${ }^{¥}$ \\ Mackenzie Presbyterian University \\ Amaury José de Rezende ${ }^{ \pm}$ \\ University of São Paulo
}

\begin{abstract}
This article analyzes the interplay of the use of management control systems, organizational learning, management decisions and the performance of health organizations. In the quantitative step, we collected data on 48 Brazilian hospitals and other health facilities by means of a survey. Principal component analysis identified three dimensions of management decisions (financial, costs and client relationship) and two performance dimensions (economic and non-monetary). Structural equation modeling confirmed the following hypotheses: (i) interactive use of the management control system is positively associated with organizational learning (OL); (ii) OL is positively associated with financial decisions and cost and process decisions; (iii) cost and process decisions and decisions related to clients are positively associated with economic performance; and (iv) cost and process decisions are also positively associated with non-monetary performance. In the qualitative step, we interviewed four key informants to discuss and interpret the results.
\end{abstract}

Keywords: Management controls. Organizational learning. Management decisions. Hospitals.

Received on August 05, 2011; reviewed on December 20, 2012; accepted on October 01, 2013; disclosed on May 7, 2014.

*Author for correspondence:

\footnotetext{
Ph.D. in Accounting from the University of São Paulo

Institution: Professor at

Mackenzie Presbyterian

University

Address: Rua da

Consolação, São Paulo -

SP - Brazil

E-mail:

oyadomari@mackenzie.br

Telephone: (11)2114-

8273
}

$\begin{array}{ll}{ }^{\Omega} \text { Master’s in Management } & ¥ ¥ \text { Ph.D. in Business } \\ \text { Control from Mackenzie } & \text { Administration from the School of } \\ \text { Presbyterian University } & \text { Economics, Administration and } \\ \text { Address: Rua Osório de } & \text { Accounting of the University of } \\ \text { Almeida, Jardim Ana Maria } & \text { São Paulo } \\ \text { - São Paulo - } & \text { Institution: Professor at } \\ \text { SP - Brazil - } & \text { Mackenzie Presbyterian } \\ \text { E-mail: } & \text { University } \\ \text { apedrique_30@yahoo.com.br } & \text { Address: Av. Santo Antônio,- } \\ \text { Telephone: (11) 4475-5345: } & \text { Vila Osasco - Osasco - SP - } \\ & \text { Brazil - E-mail: } \\ & \text { diogenesbido@ yahoo.com.br } \\ & \text { Telephone: (11) 3681-5780 : }\end{array}$

\author{
I Ph.D. in Accounting from the \\ University of São Paulo \\ Institution: Professor at the \\ University of Sao Paulo .Adress: \\ Rua Luciana Mara Ignácio, - \\ Jardim Botânico, Ribeirão Preto \\ - SP. - Brazil - E-mail: \\ amauryjr@fearp.usp.br \\ Telephone: (16) 3602-0503
}

Note from the Editor: This article was accepted by Emerson Mainardes. 


\section{INTRODUCTION}

his paper investigates relationships among management control system use, organizational learning, management decisions and performance of organizations. This theme is relevant because health organizations have highly complex processes: services, organizational structures, diversification of professionals and technologies applied to protect people's health (NOVAES, 2004). This panorama involves a set of categories that makes it difficult to identify, measure and analyze the individual impacts of these aspects on performance of these organizations.

This study is focused on Brazilian health organizations. The country's health sector is very relevant to the overall economy, but today it can be said to face unfavorable conditions in relation to other sectors. Private Brazilian hospitals and other health facilities are strongly dependent on reimbursements from the National Health System (SUS), which are often slow in coming due to budget deficits. Another aggravating factor is the low prices for services paid by private health plan operators and insurers (CREMESP, 2006; IBGE, 2008).

According to Tanaka \& Tamaki (2012, p. 822), "management decisions in the health field are complex and permeated with subjectivity and uncertainties," because of the routine dilemma of resolving health problems of the population or satisfying the demands of users. These two factors limit the time for reaching decisions. In turn, Merhy \& Cecilio (2003, p. 111) state that "only hospitals that produce the best 'products' by means of an aggressive policy of incorporating technology and ongoing improvement and control of their internal processes will survive."

Three characteristics have been identified in the sector, which combined increase the complexity of these organizations: (i) managers have to deal with services that have a strong effect on human life; (ii) the services are paid by different sources (government, patients and health insurance plans); and (iii) profit-making organizations coexist with nonprofit governmental and nongovernmental organizations in the same field. The diversity of the organizations acting in the sector creates extreme situations in terms of performance, because there are both charitable and for-profit organizations (GADELHA, 2003).

The sector in general lines has organizations characterized by providing excellent levels of services. With the recent growth of the middle class in Brazil, the health sector has attracted a good deal of interest from private equity investors, which require highly professional management. The health sector in recent years has also been marked by various 
mergers and acquisitions (PRICEWATERHOUSE, 2011). However, there are also many organizations operating in the red, such as the hospitals operated by the Santa Casa de Misericórdia Brotherhood (CARDOSO, 2012).

This panorama of the sector makes it fertile ground for research in the field of management accounting. In this line, Chenhall (2003) recommends that researchers interested in management accounting should devote more effort to analyzing specific sectors.

In the Brazilian setting, there is a gap in research into the use of management information in health organizations regarding organizational learning. For example, Escrivão Junior (2007) found that public hospitals run by the state government in the São Paulo metropolitan region produce a considerable volume of data, but their managers are unaware of the existence of such information or do not use it adequately to support hospital management decisions.

An eye on Brazilian research in management accounting allows identifying growing interest in the health sector, as reflected by the works of Camacho (2004), Ferreira (2005), Prochnick, Dias \& Carvalho (2005), Aguiar, Rezende \& Dalmácio (2007) and Miranda et al. (2007).

The international scenario is quite similar, with the main difference between Brazilian and international research being that the latter has investigated the adoption and use (diagnostic and interactive) of business budgeting and its effect on performance and strategy (ABERNETHY; STOELWINDER, 1991; ABERNETHY; BROWNELL, 1999); relationships between monetary and non-monetary indicators and the implementation of strategies (NARANJO-GIL; HARTMANN, 2006); and interactions of management control systems with managers (CINQUINI; CAMPANALE, 2010).

In this literature, concern can be noted to study how management accounting constructs can influence the performance of these organizations, although there is recognition that performance is affected by a wide range of variables, as evidenced by Gonçalves \& Quintela (2006).

In this study we followed the approach advocated by Malmi \& Grandlund (2009) for the management accounting field, with the purpose of investigating techniques that can improve organizations' performance. Hence, this article is in line with other works that have investigated the influences of management control on performance, both in Brazil 
(FREZATTI, 2006; GUERRA, 2007; ESPEJO, 2008) and internationally (HENRI, 2006; WIDENER, 2007).

Besides the mentioned studies, there are various theoretical constructs on strategy, market orientation, entrepreneurship and organizational learning that have been used in management accounting studies (BISBE; OTLEY, 2004; HENRI, 2006; WIDENER, 2007). These constructs have been associated with measuring performance in studies of strategy (HURLEY; HULT, 1998; PERIN, 2001).

Following this tradition, in this article we focus on organizational learning, which is an organizational competency characterized by the way organizations acquire and internally disseminate new knowledge (CHENHALL, 2005). The ability to learn is considered one of the main sources of a company's competitive advantage (LEITE; PORSSE, 2005; TIPPINS; SOHI, 2003) and can be stimulated by using an effective management control system (SIMONS, 2000).

Henri (2006) confirmed that interactive use of information, a typology proposed by Simons (2000), positively influences the degree of organizational learning in a sample of Canadian companies, and also demonstrated that the diagnostic use of information negatively influences organizational learning. The explanation is that diagnostic use, based on comparison of the results achieved with those budgeted, causes shortsighted orientation, negatively influencing the development of competencies.

However Widener (2007), who studied American companies, found that interactive use of the management control system is not positively and directly associated with the level of organizational learning, instead finding that interactive use is indirectly related by means of diagnostic use. Hence, the results are not yet conclusive about the relationships between use of management control systems and organizational learning, constituting an opportunity for further research.

Another research current has analyzed the effects of organizational learning, which is represented by institutionalizing of learning, by means of routines (VERA; CROSSAN, 2003; GRANT, 2008). The routine can be identified by the decisions reached by managers, whose key activity is to process information about the available alternatives in search of organizational goals (CHOO, 2006). Although management accounting is an established organizational routine, it must be recalled that decisions are also made based on sources of information other than just that from accounting (HALL, 2010). 
Instead of using the existing decision typologies, here we innovate by focusing on those arising from the use of management accounting constructs (ATKINSON et al., 2008; OYADOMARI et al., 2010), together with other decisions made in the organizational routine, identified by three interviews.

Therefore, we considered only the most relevant management decisions, defined as those with greatest influence on performance based on the perception of the respondents. Our purpose in this choice is to contribute to the "practical" interests of managers, who seek evidence of techniques that can improve their performance.

This article is organized into five sections including this introduction. The next section covers the theoretical framework, the development of hypotheses and presentation of the diagnostic use of management control systems, besides organizational learning in the Brazilian health sector and the measurement and structural model. The third section describes the research method used, while the fourth summarizes the main results and the last contains our final considerations.

\section{THEORETICAL FRAMEWORK}

\subsection{DIAGNOSTIC USE OF MANAGEMENT CONTROL SYSTEMS AND ORGANIZATIONAL LEARNING}

Diagnostic use is the traditional use of management control systems, focused on monitoring of activities, seeking to assess whether objectives are being attained and obtaining feedback to improve performance (SIMONS, 2000). This allows organizations to correct small deviations, through what has been called single-loop learning (ARGYRIS; SCHÖN, 1996), and to adjust processes so as to meet the objectives set by senior management (HENRI, 2006).

Although Henri (2006) identified a negative relation between diagnostic use and organizational learning, other authors have not confirmed this result. For example, Abernethy \& Stoelwinder (1991) found that the adoption of business budgeting makes a positive contribution to performance, by means of analyzing budget variations and proposing corrective actions, providing evidence of organizational learning. In turn, Graffon, Lillis \& Widener (2010), in a survey among business unit managers of Australian companies, identified that the diagnostic use, called feedback control use, has a positive influence on organizational learning. 
In Brazil, Oyadomari et al. (2011) identified a positive relation between diagnostic use and organizational learning, arguing that the dysfunctional effect found by international studies does not exist in Brazilian firms. The above discussion serves as the base for the following hypothesis:

H1: The diagnostic use of the management control system positively influences organizational learning.

\subsection{INTERACTIVE USE OF MANAGEMENT CONTROL SYSTEMS AND ORGANIZATIONAL LEARNING}

The main characteristics of interactive use are its recurring presence on the agenda of executives and its purpose of stimulating emerging strategies by means of innovation and organizational learning (DIEHL, 2006; 2000; HENRI, 2006; SIMONS, 1995; SIMONS, 2000). Therefore, interactive use is linked to the requirements to develop competencies, especially organizational learning, since these arise in complex environments that are undergoing transformations and are subject to strategic uncertainties. By means of this use, managers hope to develop techniques to enable them to analyze the environment and trace out new ways of acting (BISBE; OTLEY, 2004). However, in an empirical study, Widener (2007) did not find a statistically significant positive relationship between interactive use and organizational learning.

For some authors, interactive use stimulates double-loop learning, because it focuses on the formulation of new action plans and alters the premises and basic values present in decision situations (SIMONS, 2000; ARGYRIS; SCHÖN, 1996). Empirical evidence of this effect in the health sector is supplied by the study of Abernethy \& Brownell (1999), who found that interactive use allows hospital organizations to adapt to the necessary changes in the health sector by implementing new strategies.

In relation to this adaptive ability that results from the organizational learning, process, Naranjo-Gil \& Hartmann (2006) concluded, based on a survey of Spanish public hospital organizations, that interactive use exerts a stronger influence than diagnostic use on the implementation of strategies. This leads to our second hypothesis:

H2: The interactive use of the management control system positively influences organizational learning. 


\subsection{MANAGEMENT DECISIONS}

Various decision making typologies can be found in the literature, such as that which separates decisions by temporal dimensions (tactical and strategic) or by functional dimensions (financial, operational, among others) (HATCH, 1997).

In this study we decided a priori not to use any of these proposed typologies, but rather to try to validate, from an empirical standpoint, the various types of decisions based on use of the management control techniques according to the proposals of Atkinson et al. (2008, p. 53, $56,59)$.

Since accounting information is only one element of the information on which managers base decisions (HALL, 2010), we identified other decision types, based on three interviews with health sector professionals. Therefore, we measured this construct not by the frequency of decision types, but rather by the decisions' relevance, measured by the influence on organizational performance, in light of the respondents' perception.

We believe that these decisions reflect the operationalization of the organizational learning process, in line with Argyris \& Schön (1996), leading to the following hypothesis:

\section{H3: Organizational learning positively influences making relevant management} decisions.

\subsection{PERFORMANCE}

Since the relevant management decision construct was operationalized based on the influence of determined decisions on organizational performance, it is important to investigate what dimensions of performance are influenced by these decisions.

We considered the following variables to measure performance: gross revenue, profit, return on investment (CYERT; MARCH, 1992), client satisfaction and indicators of the quality of processes and overall performance (KAPLAN; NORTON, 1997).

On the matter of collecting the data to calculate the indicators, in some cases these figures were not available, even the accounting data, because they are not disclosed. Therefore, in line with the tradition of studies of strategy and management accounting, we measured the performance construct through a process of self-evaluation.

Another limitation was the difficulty of comparing the competing companies, despite being in the same sector. Hence, we defined performance as the degree of attaining the organizational objectives set by each company analyzed (DONALDSON, 2001; OTLEY, 
1980). This metric is less influenced by factors such as size and availability of resources, but is possibly more influenced by the quality of decisions and by exogenous variables that are hard to identify in surveys. Although only in exploratory form, this discussion leads to the following hypothesis:

\section{H4: The taking of relevant management decisions positively influences performance.}

\subsection{THEORETICAL MODEL, HYPOTHESES AND VARIABLES}

From the literature review presented and the hypotheses proposed, we prepared a structural model in which we related the constructs and hypotheses. Figure 1 depicts the variables and hypotheses evaluated:

H1- diagnostic use of the management control system positively influences organizational learning;

$\mathrm{H} 2$ - interactive use of the management control system positively influences organizational learning;

H3 - organizational learning positively influences making relevant management decisions;

H4 - taking of relevant management decisions positively influences performance.

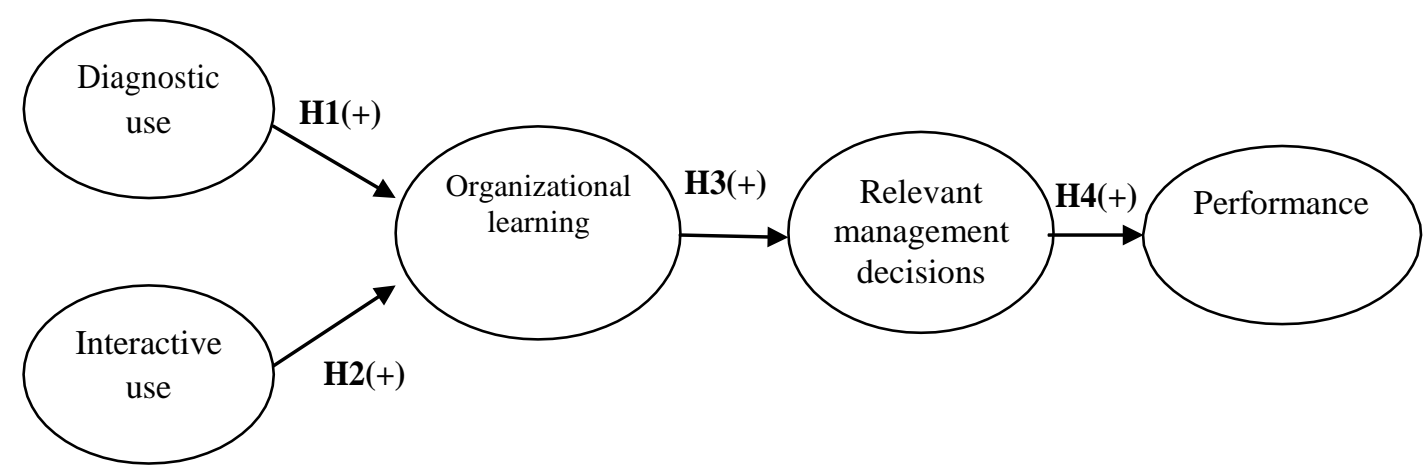

Figure 1: Theoretical Research Model

All models represent a simplification of reality, so other endogenous and exogenous variables could have been included, such as the system of management incentives and organizational culture. But due to restrictions on the scope of this study, we did not include them.

Without the presence of a system of performance-based incentives (achieving targets), managers can act differently than they would do without such a system. This can also happen 
among managers of organizations that stress cultural controls (MALMI; BROWN, 2008), because they can be less stimulated to engage in diagnostic and interactive use of the management control system.

\section{METHODLOLIGICAL PROCEDURES}

\subsection{POPULATION AND SAMPLE}

According to the Brazilian Federation of Hospitals (FEDERAÇÃO BRASILEIRA DE HOSPITAIS, 2012), the country's hospital sector has 6,690 institutions, of which 2,142 $(32 \%)$ are public hospitals and 4,548 (68\%) are private ones. Of these hospitals, 98 are associated with universities, mainly public institutions.

Because of the lack of an organized public database available for the hospital segment, to enable obtaining a probabilistic sample we used a database obtained from a firm specialized in organizing congresses and other events for companies in the health sector.

The data collection protocol involved the following procedures and steps: (i) first we sent an electronic invitation letter to 190 potential respondents; (ii) we then sent a message to those that indicated willingness to participate, containing a link to access the questionnaire (see the appendix); and (iii) a week later we called each prospective respondent by telephone to request a position on participation.

The messages with the questionnaire link were sent in March and April 2010 with the help of a trained research assistant. A total of 65 respondents filled out the questionnaire, but 17 of these questionnaires contained incomplete data, so we only considered 48 of the 190 to be valid, resulting in a valid response rate of $25.3 \%$. The respondents' profile was suitable to the research purpose, because $84 \%$ of them worked in the areas of control, accounting, finance or administration, and $56 \%$ occupied positions as managers or supervisors.

With respect to the profile the organizations, 30 were private hospital companies (63\%) and 18 were nonprofit associations. Also, 65\% of the organizations had 800 or more employees.

The samples had the bias of only including organizations that had participated in events organized by the specialized firm, but it is interesting to observe that the proportion of private hospital organizations in the sample is near that in the census of the Brazilian Federation of Hospitals (2012): 63\% and 68\%, respectively. 


\subsection{PREPARATION AND VALIDATION OF THE QUESTIONNAIRE}

We used a both a quantitative (questionnaires) and qualitative approach (interviews with managers). According to Patton (1990), qualitative and quantitative methods are alternative but not mutually exclusive research strategies, and indeed are often used together. The combined use of both has the following advantages: (i) confirmation of one by the other through triangulation; (ii) provision of richer details; and (iii) suggestion of new lines of thinking and discovery of new insights (MILES; HUBERMAN, 1994).

The preparation of the questionnaire was, when possible, based on the scales developed and used in previous studies, as shown in Chart 1.

\begin{tabular}{|l|l|}
\hline \multicolumn{1}{|c|}{ Construct } & \multicolumn{1}{c|}{ Source } \\
\hline Organizational Learning & Oyadomari et al. (2010) \\
\hline Diagnostic Use & Oyadomari (2008) \\
\hline Interactive Use & Oyadomari (2008) \\
\hline Relevant Management Decisions & Adapted from Atkinson (2008) \\
\hline Performance & Adapted from Oyadomari (2008) \\
\hline Chart 1: Source of Questions &
\end{tabular}

To improve the face validity (NETEMEYER; BEARDEN; SHARMA, 2003) of the data collection instrument, we first conducted three interviews with managers of these organizations, as presented in Chart 4 , to ascertain the adherence of the questionnaire to the reality of the health sector, since no data were available from previous studies of the same theme regarding this sector.

To improve the triangulation of the data from the interviews with those collected by other methods (SEIDMAN, 1991; YIN, 2001), we decided to conduct four more interviews to compare the responses with the quantitative results, in line with the approach undertaken by Cadez \& Guilding (2008). This strategy permits inferences on possible explanations of the results, even if contradicting other findings in the literature, which in this case is scant.

To mitigate the risk that the realization of only one interview would bias the results due to subjective aspects (vision) of the respondent about the phenomenon, we conducted other interviews, which permitted connection, comparison and verification of the comments and opinions of the participants (SEIDMAN, 1991; YIN, 2001). 


\section{ANALYSIS AND DISCUSSION OF THE RESULTS}

Because of the exploratory nature used in the operationalization and the use of some constructs, specifically decisions and performance, we opted first to apply principal component analysis, followed by application of structural equation modeling and then discussion and triangulation of the results based on the interviews conducted with the seven managers.

\subsection{PRINCIPAL COMPONENT ANALYSIS}

For organizational learning, diagnostic use and interactive use, we expected the constructs to be one-dimensional, based on the results of Oyadomari (2008). But for the relevant management decisions and performance constructs, we had no expectation about their dimensionality, so we used principal component analysis before structural equation modeling, i.e., to confirm the unidimensionality of organizational learning, diagnostic use and interactive use, as well as to determine the dimensionality of the other constructs. When more than one component was extracted by the principal component analysis, we used varimax rotation.

Below we present the clusters obtained in general, but the appendix contains details of the final results of the structural equation modeling.

Diagnostic use was measured by four indicators, and item DU4 (see the appendix) was removed for presenting low factor loading. For the other items, only one principal component was extracted (77\% extracted variance), with factor loadings between 0.85 and 0.89 and Cronbach's alpha equal to 0.85 .

Interactive use was measured by seven indicators, with only one principal component being extracted (65\% extracted variance). The factor loadings ranged from 0.62 to 0.90 and Cronbach's alpha was equal to 0.91 .

Organizational learning was measured by 12 items, and in the principal component analysis, items OL5 and OL11 (see the appendix) were dropped for having low factor loading. For the other items, only one principal component was extracted (53\% extracted variance), with factor loadings between 0.53 and 0.83 and Cronbach's alpha equal to 0.90 .

Finally, for the relevant management decisions construct, three principal components were extracted, interpreted as follows:

- Factor 1 - "Financial Decisions", because these decisions typically are connected to the organization's cash flow; 
- Factor 2 - "Decisions on Costs and Processes", which grouped decisions linked to management of costs, results and operational processes; and

- Factor 3 - "Decisions Related to Clients", which grouped decisions related to management of agreements with health plan operators/insurers that impact patients, outsourcing and exchange of doctors, which although they can have effects on costs and processes, significantly influence the client dimension.

The clustering of the variables in their respective factors can be seen in Chart 2 .

\begin{tabular}{|c|c|c|}
\hline Factor & Variable & Description \\
\hline \multirow{3}{*}{$\begin{array}{l}\text { Factor } 1 \text { - } \\
\text { Financial } \\
\text { Decisions } \\
(\text { alpha }=0.78)\end{array}$} & DE 3 & 3. Focus on actions to reduce nonpayment. \\
\hline & DE 4 & 4. Negotiation of payment with suppliers. \\
\hline & DE 5 & 5. Decisions on bank debt. \\
\hline \multirow{4}{*}{$\begin{array}{l}\text { Factor } 2 \text { - } \\
\text { Decisions on } \\
\text { Costs and } \\
\text { Processes } \\
(\text { alpha }=0.80)\end{array}$} & DE 6 & 6. Improvement of margins and results. \\
\hline & DE 7 & 7. Changes in calculation of costs. \\
\hline & DE 8 & 8. Changes in medical procedures. \\
\hline & DE 12 & 12. Decisions on inventory policies. \\
\hline \multirow{5}{*}{$\begin{array}{l}\text { Factor } 3 \text { - } \\
\text { Decisions } \\
\text { Related to } \\
\text { Clients } \\
(\text { alpha }=0.81)\end{array}$} & DE 1 & 1. Ending an agreement with a health plan operator or insurer. \\
\hline & DE 2 & 2. Changes in prices. \\
\hline & DE 9 & 9. Ceasing to offer a service. \\
\hline & DE 10 & 10. Substitution of a doctor with another who charges lower rates. \\
\hline & DE 11 & 11. Outsourcing of services. \\
\hline
\end{tabular}

Chart 2: Variables and factors of the decisions construct based on accounting information

Note: Based on use of principal components extraction and varimax rotation; the variables maintained in the model presented favor loadings greater than 0.6.

The variables of the performance construct were grouped in two factors: Factor 1 Economic Performance, and Factor 2 - Non-Monetary Performance, as presented in Chart 3.

\begin{tabular}{l|c|l}
\hline \multicolumn{1}{c|}{ Factor } & Variable & \multicolumn{1}{c}{ Description } \\
\hline Factor 1 - Economic & P 1 & 1. Gross revenue \\
Performance & P 2 & 2. Profit \\
\cline { 2 - 3 }$($ alpha $=0.89)$ & P 3 & 3. Return on investment \\
\cline { 2 - 3 } $\begin{array}{l}\text { Factor 2 - Non-Monetary } \\
\text { Performance } \\
\text { (alpha }=0.88)\end{array}$ & P 4 & 4. Client satisfaction \\
\cline { 2 - 3 } & P 5 & 5. Process quality indicators \\
\cline { 2 - 3 } & P 6 & 6. Overall performance \\
\hline
\end{tabular}

Chart 3. Performance Variables and Factors

Note: Based on use of principal components extraction and varimax rotation; the variables maintained in the model presented favor loadings greater than 0.6.

After the cluster analysis of the variables and with the factors obtained, we expanded the theoretical model initially proposed (Figure 1) by separating the "Decisions" construct 
into three dimensions and the "Performance" construct into two dimensions, as presented in Figure 2.

We should mention that the grounds for hypotheses $\mathrm{H} 1$ and $\mathrm{H} 2$ were already justified preliminarily and the other sub-hypotheses are derived from hypotheses $\mathrm{H} 3$ and H4, also previously justified. However, we should also stress the exploratory aspect of the relationship of the different dimensions of decisions and the two types of performance.

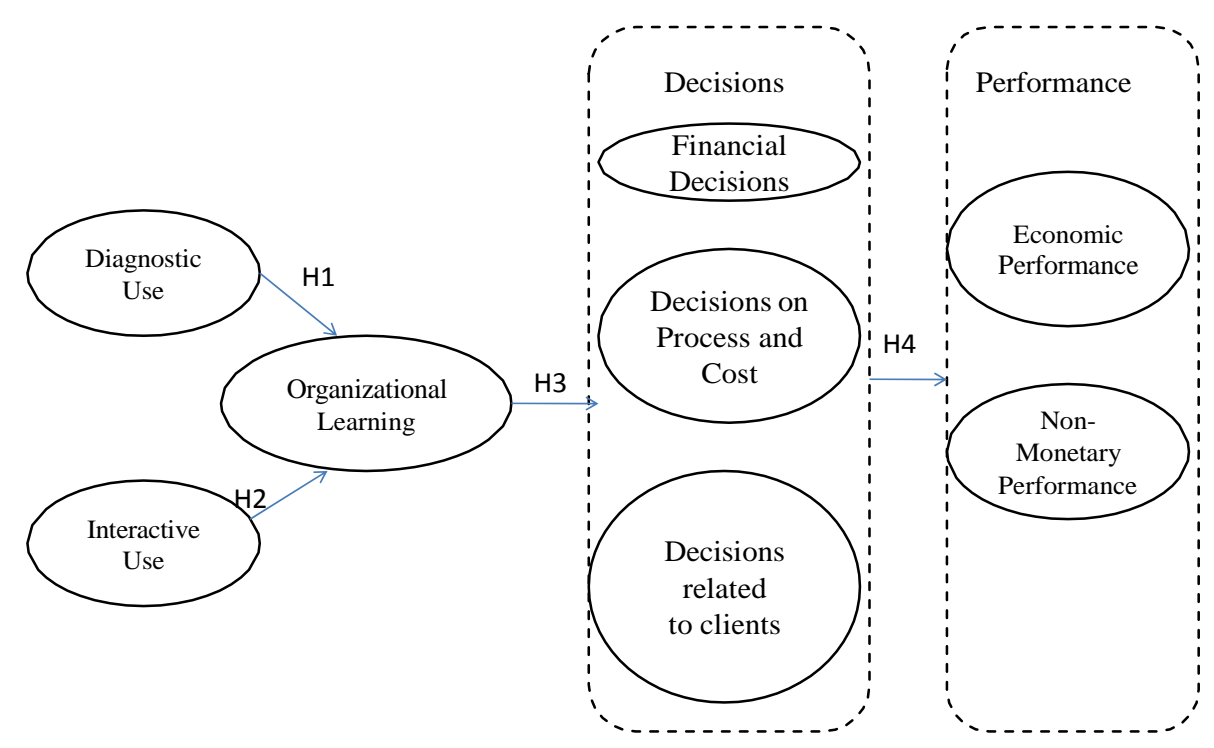

Figure 2: Expanded Theoretical Model

\subsection{STRUCTURAL EQUATION MODELING}

(A) For empirical analysis of the relationships, we used structural equation modeling, which in general is a method guided more by theory than by empirical results (HAIR JR. et al., 2005). However, the partial least squares path modeling method (pls-pm) is recommended in the initial phase of theoretical development, as a way to test and validate exploratory models (HENSELER; RINGLE; SINKOVICS, 2009, p. 282).

(B) Another advantage is that this technique is suitable for small samples (SMITH; LANGFIELD-SMITH, 2004), which has contributed to its frequent use in accounting research (HALL, 2008; CHAPMAN; KINH, 2009, HARTMANN; SLAPNICAR, 2009). As done by hartmann \& slapnicar (2009), here we also used the smartpls $2.0 \mathrm{~m} 3$ software (RINGLE; WENDE; WILL, 2005). 
(C) The analysis of the results was based on the steps recommended by Hair Jr. et al. (2005), Hair Jr. et al. (2011), Henseler et al. (2009) and Tenenhaus et al. (2005).

\subsubsection{Evaluation of the measurement model}

Three variables (OL-6, OL-7 and OL-11) intended to measure the Organizational Learning construct did not present convergent validity, with loadings under 0.60 . Therefore, we excluded these variables. Then we ran the adjusted model without these indicators. The main statistical results are presented in Tables 1,2 and 3.

Regarding convergent validity, all the indicators presented significant factor loadings ( $\mathrm{p}$ $<0.05$ ) greater than 0.6 (see appendix), and the constructs presented average extracted variance $(\mathrm{AEV})$ higher than 0.50 (Table 1). They also presented compound reliability indexes and Cronbach's alpha greater than 0.7 (HAIR JR. et al., 2005; HAIR JR. et al., 2011; HENSELER et al., 2009; TENENHAUS et al., 2005).

Table 1 shows there is discriminant validity at the level of the constructs. According to Fornell \& Larcker (1981), if the correlations are lower than the square root of the average extracted variance (AEV), there is discriminant validity, i.e., the constructs are correlated, but are still distinct from each other.

The discriminant validity was also assured by the level of the indicators, because comparative analysis of the factor loadings (cross loadings) allowed identifying the indicators without high factor loadings in their constructs and low in the others, so they were dropped from the measurement model (appendix).

Table 1: Matrix of correlation between the latent variables and validity and reliability assessment

\begin{tabular}{|c|c|c|c|c|c|c|c|c|}
\hline Latent variables & 1 & 2 & 3 & 4 & 5 & 6 & 7 & 8 \\
\hline 1. Diagnostic Use & 0.878 & & & & & & & \\
\hline 2. Interactive Use & 0.479 & 0.838 & & & & & & \\
\hline 3. Organizational Learning & 0.394 & 0.731 & 0.776 & & & & & \\
\hline 4. Decisions - Financial & 0.235 & 0.444 & 0.440 & 0.838 & & & & \\
\hline 5. Decisions - Costs \& Processes & 0.367 & 0.566 & 0.402 & 0.565 & 0.795 & & & \\
\hline $\begin{array}{l}\text { 6. Decisions - Relationship with } \\
\text { Clients }\end{array}$ & 0.219 & 0.172 & 0.241 & 0.426 & 0.372 & 0.747 & & \\
\hline 7. Economic Performance & 0.227 & 0.301 & 0.210 & 0.419 & 0.495 & 0.598 & 0.910 & \\
\hline 8. Non-Monetary Performance & 0.386 & 0.425 & 0.307 & 0.328 & 0.571 & 0.175 & 0.476 & 0.898 \\
\hline Scale $($ appendix $)=$ & (a) & (a) & (b) & (c) & (c) & (c) & (d) & (d) \\
\hline Mean $=$ & 3.6 & 3.6 & 3.8 & 3.6 & 3.2 & 2.6 & 2.4 & 3.3 \\
\hline
\end{tabular}




\begin{tabular}{|c|c|c|c|c|c|c|c|c|}
\hline Standard deviation $=$ & 1.08 & 0.96 & 0.90 & 1.04 & 1.15 & 1.14 & 0.84 & 0.79 \\
\hline erage extracted variance $=$ & 0.771 & 0.703 & 0.602 & 0.703 & 0.632 & 0.558 & 0.827 & 0.806 \\
\hline Compound reliability $=$ & 0.910 & 0.934 & 0.923 & 0.876 & 0.873 & 0.863 & 0.935 & 0.926 \\
\hline Cronbach's alpha $=$ & 0.853 & 0.915 & 0.905 & 0.789 & 0.808 & 0.805 & 0.895 & 0.879 \\
\hline
\end{tabular}

Source: Research data.

Nota 1: Correlations greater than $|0.29|$ are significant at $5 \%$ (two-tailed) and correlations greater than $|0.39|$ are significant at $1 \%$ (two-tailed).

Nota 2: The diagonal on boldface contains the square roots of the average extracted variance (AEV).

Legend: $(\mathrm{a})=1$ (never used) to 5 (always used)

(b) $=1$ (totally disagree) to 5 (totally agree)

(c) $=1$ (little influence) to 5 (great influence)

(d) $=1$ (much less than expected) to 5 (much more than expected)

\subsubsection{Evaluation of the structural model}

The PLS-PM technique provides goodness-of-fit indexes of the model, as occurs with linear structural relations (LISREL) modeling (based on the reproduction of the covariance matrix), because its objective is to maximize the explanation of the variance of the dependent variables rather than to reproduce the covariance matrix.

Despite this, to obtain some information about the adequacy of the model in general (measurement and structural), we performed the goodness-of-fit test proposed by Tenenhaus et al. (2005), given by the geometric mean between the AEV and average $\mathrm{R}^{2}$, obtaining 0.53 , which can be considered adequate according to Wetzels et al. (2009, p.187).

For better visualization of the results attained, in Table 2 we show the hypotheses tested and the results obtained.

Table 2: Tests of the Hypotheses - structural coefficients

\begin{tabular}{|c|c|c|c|c|}
\hline Hypotheses & Result & Coefficient & P-value & $\mathbf{R}^{2}$ \\
\hline $\begin{array}{l}\text { H1 - Diagnostic use is positively associated with } \\
\text { organizational learning. }\end{array}$ & Not validated & 0.058 & 0.620 & \multirow{2}{*}{$53.6 \%$} \\
\hline $\begin{array}{l}\mathrm{H} 2 \text { - Interactive use is positively associated with } \\
\text { organizational learning. }\end{array}$ & Validated & 0.703 & 0.000 & \\
\hline $\begin{array}{l}\text { H3.1 - Organizational learning is positively associated } \\
\text { with Financial Decisions. }\end{array}$ & Validated & 0.440 & 0.008 & $19.3 \%$ \\
\hline $\begin{array}{l}\text { H3.2 - Organizational learning is positively associated } \\
\text { with decisions on costs and processes. }\end{array}$ & Validated & 0.402 & 0.005 & $16.2 \%$ \\
\hline $\begin{array}{l}\text { H3.3 - Organizational learning is positively associated } \\
\text { with decisions related to clients. }\end{array}$ & Not validated & 0.241 & 0.212 & $5.8 \%$ \\
\hline $\begin{array}{l}\text { H4.1 - Financial decisions are positively associated with } \\
\text { economic performance }\end{array}$ & Not validated & 0.056 & 0.738 & \multirow{2}{*}{$44.6 \%$} \\
\hline $\begin{array}{l}\text { H4.3 - Decisions on costs and processes are positively } \\
\text { associated with economic performance. }\end{array}$ & Validated & 0.290 & 0.040 & \\
\hline
\end{tabular}




\begin{tabular}{l|c|c|c|c}
\hline $\begin{array}{l}\text { H4.5 - Decisions related to clients are positively } \\
\text { associated with economic performance. }\end{array}$ & Validated & $\mathbf{0 . 4 6 6}$ & $\mathbf{0 . 0 0 0}$ & \\
\hline $\begin{array}{l}\text { H4.2 - Financial decisions are positively associated with } \\
\text { non-monetary performance. }\end{array}$ & Not validated & 0.023 & 0.921 & \\
\hline $\begin{array}{l}\text { H4.4 - Decisions on costs and processes are positively } \\
\text { associated with non-monetary performance. }\end{array}$ & Validated & $\mathbf{0 . 5 7 7}$ & $\mathbf{0 . 0 0 0}$ & \multirow{2}{*}{$32.8 \%$} \\
\hline $\begin{array}{l}\text { H4.6 - Decisions related to clients are positively } \\
\text { associated with non-monetary performance. }\end{array}$ & Not validated & -0.050 & 0.718 & \\
\hline
\end{tabular}

Source: Research data.

Note 1: The p-values were estimated by bootstrapping, with 48 cases and 1,000 resamples.

Note 2: Since the sample was small $(n=48)$, we tested the statistical power to assess whether the non-significant results were caused by this reason. The G*Power 3 program (Buchner et al., 2006) indicated statistical power of $80 \%$ at 5\% significance (recommended by Hair Jr. et al., 2005) in a sample of 48 cases and 3 predictors (which was the most critical situation to determine the sample size). Furthermore, as recommended by Chin \& Newsted (1999), any $\mathrm{R}^{2}$ greater than $20 \%$ will be significant. The $\mathrm{R}^{2}$ values were $44 \%$ for economic performance and $33 \%$ for non-financial performance, so despite the small sample size, it was sufficient to test the proposed hypotheses.

\subsubsection{Analysis and discussion of the hypotheses tested}

When using multiple sources of evidence, it is necessary make sure there is convergence and conditions to validate the results found, by means of triangulation of information, data, evidence and even theories (MARTINS, 2008), so that the conclusions and discoveries will be more convincing and accurate, because they are supported by a set of corroborations.

Therefore, to triangulate the results obtained from the quantitative data, we conducted seven interviews with professionals from health organizations, as shown in Chart 4 . Three of these interviews served to support the validity of the questionnaire, while the other four were performed during the process of analyzing the data.

\begin{tabular}{c|c|c|c|c}
\hline Respondent & Position & Corporate structure & Description & $\begin{array}{c}\text { Number of } \\
\text { employees }\end{array}$ \\
\hline 1 & Controller & $\begin{array}{c}\text { For-profit limited } \\
\text { liability company }\end{array}$ & Large hospital & 1,500 \\
\hline 2 & $\begin{array}{c}\text { Assistant to the } \\
\text { CEO }\end{array}$ & $\begin{array}{c}\text { For-profit limited } \\
\text { liability company }\end{array}$ & Medium hospital & 830 \\
\hline 3 & Controller & $\begin{array}{c}\text { For-profit limited } \\
\text { liability company }\end{array}$ & Diagnostic medicine clinic & 280 \\
\hline 4 & $\begin{array}{c}\text { Nursing } \\
\text { Manager }\end{array}$ & $\begin{array}{c}\text { Charitable } \\
\text { organization }\end{array}$ & Philanthropic association & 80 \\
\hline 6 & Cost Manager & $\begin{array}{c}\text { For-profit limited } \\
\text { liability company }\end{array}$ & Large hospital & 1,500 \\
\hline 7 & Supervisor of & $\begin{array}{c}\text { For-profit limited } \\
\text { liability company }\end{array}$ & Large hospital & 1,200 \\
\hline
\end{tabular}

Chart 4: Characteristics of the interviewees 
To facilitate discussion of the results, we restated the hypotheses after making a general comment on each construct of the structural model.

\section{Use of management control and organizational learning}

The diagnostic use of management control (H1) was not significant, but interactive use explained $53.6 \%$ of the variance of organizational learning $(\mathrm{H} 2)$. Below we discuss these results in light of the theoretical framework and the interviews conducted.

H1: The diagnostic use of the management control system positively influences organizational learning. Not validated.

The coefficient was not significant, a result that diverges from that found by Henri (2006), who identified a negative influence of the diagnostic use on organizational learning. The result found here suggests that in the organizations studied, the traditional use of management control does not have a positive effect on the sharing of information and dissemination of knowledge.

Evidence of this came from respondent 5, who mentioned that managers justify any deviations between the results budgeted and realized, seeking to understand such variations as well as to formulate possible corrections of processes.

A possibility, although not investigated here, is that in these organizations, although there is an emphasis on using the budget as a base to evaluate performance, this practice has not generated significant effects on organizational learning, in function of the low indexes of attaining economic performance, as shown in the appendix.

H2: The interactive use of the management control system positively influences organizational learning. Validated.

This result suggests that in the health organizations in the present sample, the interactive use of management control positively stimulates organizational learning, a finding in agreement with that of Henri (2006). This is also coherent with Simons (2000), according to whom the focus of interactive use is to deal with strategic uncertainties, something strongly present in Brazil given the intense competition, high level of complexity and ongoing consolidation of companies in the health care sector.

Confirming this result, respondents 5,6 and 7 all mentioned that the market is very dynamic and that companies are constantly on the lookout for innovations, mainly in the area of equipment. 


\section{H3: Organizational learning is positively associated with relevant management} decisions.

Since the principal component analysis applied to the relevant management decisions construct generated three distinct dimensions, we divided this hypothesis into three subhypotheses: H3.1, H3.2 and H3.3.

Organizational learning presented a significant relation with two of the three dimensions of relevant management decisions, explaining $19.4 \%$ of the variance of the "financial" dimension, $16.3 \%$ of the variance of the "costs and processes" dimension but only $7.9 \%$ of the "relationship with clients" dimension (H3.1, H3.2 and H3.3, respectively).

H3.1: Organizational learning is positively associated with financial decisions. Validated.

This result suggests that the degree of organizational learning influences the making of relevant financial decisions. In other words, there is an environment that favors the organizational learning process and influences financial decisions. These decisions can be both of the single-loop and double-loop type (ARGYRIS; SCHÖN, 1996), such as alterations in average payment periods and new strategies to obtain long-term financing.

This result also indicates there is a routine discussion of the financial situation of the organizations, in the form of weekly meetings, and that this contributes to the survival in the short run, crucial at a moment when news published in the business press reveals the grave situation faced by nonprofit health organizations, such as the hospitals run by the Santa Casa de Misericordia Brotherhood (CARDOSO, 2012).

Empirical evidence of this finding was supplied by respondent 1, who indicated that his organization typically faces cash flow difficulties on the 5th and 20th days of the month, when salaries are paid, mainly because of the slow payment by health plan operators/insurers. In turn, respondents 6 and 7 mentioned that cash flow management is a routine activity, including monitoring of reimbursements denied by health plan operators/insurers.

H3.2: Organizational learning is positively associated with decisions on costs and processes. Validated.

This result suggests that the organizational learning process is positively related to decisions on costs and processes, demonstrating that the sharing of ideas propitiates the 
making of decisions and affects the activities of these organizations, with respect to both incremental and more profound changes (ARGYRIS; SCHÖN, 1996).

This might be influencing the way managers are calculating costs and modifying medical procedures, as addressed in the study of Italian hospital organizations by Cinquini \& Campanale (2010), besides modifications of inventories and procurement schedules.

Respondent 2 mentioned that his company is purchasing more generic drugs and domestically produced prostheses because these are cheaper, providing evidence of an effort to reduce costs.

\section{H3.3: Organizational learning is positively associated with decisions related to} clients. Not validated.

This result suggests that the organizational learning process, with a smaller coefficient than for the other two dimensions, does not have a positive association with decisions related to clients. This result is in a certain way similar to that found by Perin et al. (2006), in a study of the electrical-electronics industry, where the results showed that double-loop learning had a low coefficient in relation to the response capacity.

The evidence here shows that decisions to end or maintain agreements with health plan operators/insurers is very common, as indicated by respondent 1 , and that organizations discuss the best mix of services to maximize profits, as mentioned by respondent 3 . However, these decisions, for being more of a strategic nature, are possibly being reached at the senior management level, without necessarily being stimulated by discussion and exchange of ideas at different organizational levels.

This can be explained by the high bargaining power of clients (health plan operators and insurers), the long-term contracts involved and the heavy regulations faced by hospitals, themes that are sensitive to the performance of these organizations.

\section{H4: Decisions are positively associated with performance.}

Based on the principal component analysis of the variables of the performance and decisions constructs, we divided this hypothesis into six sub-hypotheses. For a question of better flow of the text, here we do not follow the order of these hypotheses, instead undertaking an analysis that contemplates the conceptual proximity of these hypotheses.

An initial analysis shows that $43.7 \%$ of the variance of the economic performance construct was explained by the "relationship with clients" and "costs and processes" 
dimensions (H4.3 and H4.5), and the relationship was not significant with the "financial" dimension (H4.1). In turn, $33.1 \%$ of the variance of the non-financial performance was explained by the "costs and processes" dimension (H4.4), and there were no significant relations with the other two decision dimensions (H.4.2 and H.4.6).

These results suggest that the performance construct has more than one dimension and that these dimensions (economic and non-monetary) are influenced differently by the various dimensions of decisions. This is a contribution to the Brazilian literature, because most previous studies have used performance as a single construct (FREZATTI, 2006, ESPEJO, 2008, OYADOMARI, 2009, HENRI, 2006, WIDENER, 2007).

H4.1: Financial decisions are positively associated with economic performance. Not validated.

This hypothesis involves financial decisions focused on management of procurement, payment of suppliers and bank indebtedness, and their relationship with the indicators gross revenue, profit and return on investment. The non-validation of this relationship can indicate that financial decisions have low importance for meeting economic performance indicators. Therefore, it can be inferred that these financial decisions are basic conditions for the organization's short-term survival, so they do not have a large influence on the economic performance, although they produce reflections on expenses, and in the final analysis have an impact on the net income and return on equity.

H4.3: Decisions on costs and processes are positively associated with economic performance. Validated.

In turn, the validation of this hypothesis suggests that because the hospital organizations studied face an extremely competitive market, their focus is on decisions regarding costs and processes, which have a stronger effect on economic performance.

It is by management of operations that performance measured by gross revenue, profit and return on investments is attained, as shown by Zanardo (2004), and the monitoring of margins and results stimulates performance measured by economic indicators.

Additionally, these results suggest that Brazilian hospital organizations are correct to invest in training their employees, as mentioned by respondent 1 , because improved worker competencies should positively influence operational efficiency. 
H4.2: Financial decisions are positively associated with non-monetary performance. Not validated.

Hypothesis H4.2 was not validated, indicating no relationship between financial decisions and non-monetary performance. In principle this is to be expected, since these decisions do not produce directly effects on performance measured by non-monetary indicators (here measured by client satisfaction, indicators of the quality of processes and overall performance). [It would seem that overall performance by definition contains monetary elements, so it should be deleted here.] [I cannot comment on the literature, since I only briefly consulted a few of the references (usually just the abstracts) listed by the authors. However, the adjective "overall" by definition means both monetary and non-monetary aspects, just as the expression "overall population" includes both males and females, young and old people, etc. Just because the literature has used overall performance as non-monetary performance does not make it correct.]

As previously mentioned, financial decisions act to assure the short-term survival and functioning of the organization, but without influencing the indicators more focused on longterm performance.

H4.4: Decisions on costs and processes are positively associated with non-monetary performance. Validated.

This result is important by indicating that decisions on costs and processes positively influence the perception of non-monetary performance, such as quality of processes, client satisfaction and overall performance.

The correlation between the variables of changes in medical procedures and nonmonetary performance was high (around 0.5), suggesting these changes have a positive effect on non-monetary performance, and to a greater degree on indicators of the quality of processes.

H4.5: Decisions related to clients are positively associated with economic performance. Validated.

This result suggests that actions connected with ending or maintaining agreements with health plan operators and insurers, as well as alteration of prices for services rendered, have a positive effect on the economic results. 
These decisions could be observed in the comments of respondent 5, regarding the decision to adjust the cost reimbursement tables under one such agreement so as not to be disqualified by an important health plan operator, and of respondent 6 , who mentioned that the offer of new services, made possible by investments in refurbishment and expansion of installations and purchase of new equipment, boosted revenues.

The empirical results demonstrate that actions recommended by experts (SALU, 2012) produce positive effects on economic performance. Carrying out such actions can be a reaction of hospital organizations to the fact that many health plan operators/insurers do not differentiate prices suitably in function of the complexity of the services (CAMACHO; ROCHA, 2009).

H4.6: Decisions related to clients are positively associated with non-monetary performance. Not validated.

A possible explanation for this result is that routine cancellation of agreements with smaller health plan operators can negatively affect the satisfaction of consumers, something that also applies to increases in rates. A complementary analysis of the correlations between these variables showed low or even negative figures, but they were not statistically significant.

All the respondents mentioned that conducting periodic client satisfaction surveys was an organizational practice, and the data from the quantitative study showed this variable had a better average in terms of performance than the economic indicators (gross revenue, profit and return no investment).

This contrast, in terms of differences of the performance dimension, shows that these organizations appear to weigh and emphasize the long-term dimension, even though facing difficulties in the short run. This perspective could be equilibrated by the use of balanced scorecard analysis, which would enable equalization of the interests of the different stakeholders involved with health organizations (FUNCK, 2007).

\section{FINAL CONSIDERATIONS}

The purpose of this study was to identify the interplay of the use of management control systems, organizational learning, decisions and performance in Brazilian hospital organizations. Although it can be classified as exploratory, we believe the findings have contributed to the literature and the practice of management accounting, mainly in the following aspects: (1) methodological - by combining qualitative methods to identify 
questions to be applied in the survey, and also using interviews to triangulate with the qualitative results, which is in line with the practice in international studies in management accounting; (2) theoretical - by developing a new construct, relevant management decisions, based on the literature and practice, with the advantage of being described in a more adequate language to the field of practices, besides being usable in new academic studies; (3) the findings - by demonstrating the positive associations of decisions related to clients and decisions about costs and processes with economic performance, besides showing that the organizations studied have high averages in the non-monetary performance dimension, in detriment to low economic performance indexes.

Based on the results, discussed on section 4, we can make some recommendations to control professionals who work in these organizations that can be useful to improve economic performance. Chiefly we suggest improving the diagnostic use of the management control system, to positively influence the level of organizational learning, but without ignoring interactive use, since it has a positive effect on reaching more coherent decisions to improve organizational performance.

Another important contribution is the validation of the expression "You obtain what you measure." In other words, there are correlations between the types of decisions and the performance dimensions, so organizations should take this into account in the process of choosing performance indicators. A final important finding is that hospital organizations appear to prioritize service and client satisfaction, even though they face situations of unsatisfactory economic performance. Although there are opportunities for better management, there must be a better balance of forces among hospitals, health plan operators, insurers and the government.

Since this was an exploratory study, some limitations can be mentioned: (i) the results cannot be generalized, because of the non-random sample used; (ii) the results are in the majority based on perceptions of professionals working in the control area, so the results could have been different if the respondents had been drawn from the operational area; and (iii) performance was measured by self-perception rather than by accounting indicators.

As avenues of future research, we can recommend using the organizational learning construct in segregated fashion: single-loop and double-loop organizational learning. Finally, it would be interesting to carry out longitudinal studies, which could provide stronger evidence to propose causal inferences. 


\section{REFERENCES}

ABERNETHY, M. A.; BROWNELL, P. The role of budgets in organizations facing strategic change: an exploratory study. Accounting, Organizations and Society, v.24, n.3, p.189-204, 1999.

ABERNETHY, M. A.; STOELWINDER, J. Budget use, task uncertainty, system goal orientation and subunit performance: a test of the "fit" Hypothesis in not-for-profit hospitals. Accounting Organizations and Society, v.16, n.2, p.105-120, 1991.

AGUIAR, A. B.; REZENDE, A. J.; DALMÁCIO, F. Z. Uma aplicação do time-driven ABC model no setor de serviço hospitalar: a nova abordagem do ABC proposta por Kaplan e Anderson. Contabilidade Vista e Revista, v.18, n.2, p.11-34, 2007.

ARGYRIS, C.; SCHÖN, D. Organizational learning: theory, method, and practice. Massachusetts: Addison-Wesley, 1996.

ATKINSON, A. A.; KAPLAN, R. A.; YOUNG, M. S. Contabilidade gerencial. 2. ed. São Paulo: Atlas, 2008.

BISBE, J.; OTLEY, D. The effects of the interactive use of management control systems on product innovation. Accounting, Organizations and Society, v.29, n.8, p.709-737, 2004.

BUCHNER, A. et al. Software G*Power: versão 3.1.6. Germany: Universidade Kiel, 2006. Disponível em: <http://www.psycho.uni-duesseldorf.de/abteilungen/aap/gpower3/downloadand-register>. Acesso em: 26 mar. 2013.

CADEZ, S.; GUILDING. C. An exploratory investigation of an integrated contingency model of strategic management accounting. Accounting, Organizations and Society, v.33, n.7-8, p.836-863, 2008.

CAMACHO, R. R. Custeio alvo em serviços hospitalares: um estudo sobre o enfoque da gestão estratégica de custos. 2004. 159 f. Dissertação (Mestrado em Ciências Contábeis) Programa de Pós-Graduação em Ciências Contábeis da Faculdade de Economia, administração e Contabilidade da Universidade de São Paulo (FEA/USP), São Paulo, 2004.

CAMACHO, R.R.; ROCHA, W. Preços e níveis de complexidade dos serviços praticados por hospitais privados junto à operadoras de planos de saúde. In: CONGRESSO USP DE CONTROLADORIA E CONTABILIDADE, 9., 2009, São Paulo (SP). Anais... São Paulo: USP, 2009. Disponível em: <http://www.congressousp.fipecafi.org/artigos92009/122.pdf>. Acesso em: 26 mar. 2013.

CARDOSO, D. Santas Casas do ABCD estão sufocadas. Diário de SP. 27/04/2012. Disponível em:

<http://www.diariosp.com.br/noticia/detalhe/20050/Santas+Casas+do+ABCD+estao+sufocad as>. Acesso em: 26 mar. 2013.

CHAPMAN, C. S.; KIHN, L. A. Information system integration, enabling control and performance. Accounting, Organizations and Society, v.34, n.2, p.151-169, 2009. 
CHENHALL, R. H. Management control systems design within its organizational context: findings from contingency-based research and directions for the future. Accounting, Organizations and Society, v.28, n.2-3, p.127-168, 2003.

CHENHALL, R.H. Integrative strategic performance measurement systems, strategic alignment of manufacturing, learning and strategic outcomes: an exploratory study. Accounting, Organizations and Society, v.30, n.5, p.395-422, 2005.

CHIN, W. W.; NEWSTED, P. R. Structural equation modeling analysis with small sample using partial least squares. In: HOYLE, R. H. (Ed.). Statistical strategies for small sample research. Thousand Oaks: Sage Publications, 1999. p.307-341.

CHOO, C. W. The knowing organization: how organizations use information to construct meaning, create knowledge, and make decisions. 2. ed. New York: Oxford University Press, Inc., 2006.

CINQUINI, L.; CAMPANALE, C. Integrative-interactive management accounting in healthcare. European Accounting Congress, Istanbul, 2010.

CRM-SP. Conselho Regional de Medicina do Estado de São Paulo. 2006. Disponível em: <http://www.cremesp.org.br/>. Acesso em: 15 fev. 2010.

CYERT, R. M.; MARCH, J. G. A behavioral theory of the firm. 2. ed. Massachusetts: Blackwell Publishers, Inc., 1992.

DIEHL, C. A. Gestão estratégica de custos: identificando o alinhamento estratégico em uma empresa de segurança. Contabilidade Vista \& Revista, v.17, n.1, p.69-97, 2006.

DONALDSON, L. The contingency theory of organization. Thousand Oaks: Sage, 2001.

ESCRIVÃO JUNIOR, A. Uso da informação na gestão de hospitais públicos. Ciência \& Saúde Coletiva. v.12, n.3, p. 655-666, 2007.

ESPEJO, M. M. S. Perfil dos atributos do sistema orçamentário sob a perspectiva contingencial: uma abordagem multivariada. 2008. Tese (Doutorado) - Faculdade de Economia, Administração e Contabilidade, Universidade de São Paulo (FEA/USP), São Paulo, 2008.

FEDERAÇÃO BRASILEIRA DE HOSPITAIS. Indicadores de Saúde: hospitais no país. 2012. Disponível em: <http://fbh.com.br/2011/06/06/hospitais-no-pais/>. Acesso em: 26 mar. 2013.

FERREIRA, L. N. Custos logísticos hospitalares: um estudo empírico. In: CONGRESSO BRASILEIRO DE CUSTOS, 12., 2005, São Paulo (SP). Anais... São Paulo: CBC, 2005.

FORNELL, C.; LARCKER, D. F. Evaluating structural equation models with unobservable variables and measurement error. Journal of Marketing Research, v.18, p.39-50, 1981.

FREZATTI, F. O paradigma econômico na contabilidade gerencial: um estudo empírico sobre a associação entre taxas de retorno sobre o patrimônio líquido e diferentes perfis da contabilidade gerencial. Revista de Administração, v.41, n.1, p.5-17, 2006. 
FUNCK, E. The balanced scorecard equates interest in healthcare organizations. Journal of Accounting \& Organizational Change, v.3, n.2, p.88-103, 2007.

GADELHA, C. A. G. O complexo industrial da saúde e a necessidade de um enfoque dinâmico na economia da saúde. Ciência \& Saúde Coletiva, v.8, n.2, p.521-535, 2003.

GONÇALVES, A. R.; QUINTELA, R. H. The role of internal and external factors in the performance of brazilians companies and its evolution between 1990 and 2003. BAR Brazilian Administration Review, v.3, n.2, p.1-14, 2006.

GRAFON, J.; LILLIS, A. M.; WIDENER, S. K. The role of performance measurement and evaluation in building organizational capabilities and performance. Accounting,

Organizations and Society, v.35, n.7, p. 689-706, 2010.

GRANT, R. M. Contemporary strategy analysis. Blackwell (UK): Wiley, 2008.

GUERRA, A. R. Arranjos entre fatores situacionais e sistema de contabilidade gerencial sob a ótica da teoria da contingência. 2007. Dissertação (Mestrado) Faculdade de Economia, Administração e Contabilidade, Universidade de São Paulo (FEA/USP), São Paulo, 2007.

HAIR JR., J. F. et al. Análise multivariada de dados. 5. ed. Porto Alegre: Bookman, 2005.

HAIR JR., J. F.; RINGLE, C. M.; SARSTEDT, M. PLS-SEM: indeed a silver bullet. The Journal of Marketing Theory and Practice, v.19, n.2, p.139-152, 2011.

HALL, M. The effect of comprehensive performance measurement systems on role clarity, psychological empowerment and managerial performance. Accounting, Organizations and Society, v.33, n.2-3, p.141-163, 2008.

Accounting information and managerial work. Accounting, Organizations and Society, v. 35, n.3, p. 301-315, 2010.

HARTMANN, F.; SLAPNICAR, S. How formal performance evaluation affects trust between superior and subordinate managers. Accounting, Organizations and Society, v.34, n.6-7, p.722-737, 2009.

HATCH, M. J. Organization theory: modern, symbolic, and postmodern perspectives. New York: Oxford University Press Inc., 1997.

HENRI, J. F. Management control systems and strategy: a resource-based perspective. Accounting, Organizations and Society, v.31, n.6, p.529-558, 2006.

HENSELER, J.; RINGLE, C. M.; SINKOVICS, R. R. The use of partial least squares path modeling in International Marketing. Advances in International Marketing, v.20, p.277319, 2009.

HURLEY, R. F.; HULT, G. T. M. Innovation, market orientation, and organizational learning: an integration and empirical examination. Journal of Marketing, v.62, n.3, p.42$54,1998$. 
IBGE. Instituto Brasileiro de Geografia e Estatística. 2008. Disponível em: <www.ibge.gov.br>. Acesso em: 12 ago. 2009.

KAPLAN, Robert S.; NORTON, David P. A estratégia em ação: balanced scorecard. Rio de Janeiro: Campus, 1997.

LEITE, J. B; PORSSE, M. C. S. Competição baseada em competências e aprendizagem. organizacional: em busca da vantagem competitiva. In: RUAS, R. L. et al. (Org.).

Aprendizagem organizacional e competências. Porto Alegre: Bookman, 2005. p.56-69.

MALMI, T., BROWN, D. Management control systems as a package: opportunities, challenges and research directions. Management Accounting Research, v.19, n.4, p.287300, 2008.

MALMI, T.; GRANDLUND, M. In search of management accounting theory. European Accounting Review, v.18, n.3, p.597-620, 2009.

MARTINS, G. A. Estudo de caso: uma reflexão sobre a aplicabilidade em pesquisas no Brasil. RCO - Revista de Contabilidade e Organizações, v.2, n.2, p.8-18, 2008.

MERHY E. E.; CECÍLIO, L. C. O. O singular processo de coordenação dos hospitais. Revista Saúde em Debate, v.22, n.64, p.110-122, 2003.

MILES, M. B.; HUBERMAN, A. M. Qualitative data analysis. 2. ed. Thousand Oaks: Sage Publications, 1994.

MIRANDA, J. G. et al. Custeio ABC no ambiente hospitalar: um estudo nos hospitais universitários e de ensinos. Revista Contabilidade e Finanças, n.44, p. 33-43, 2007.

NARANJO-GIL, D.; HARTMANN, F. How top management teams use management accounting Systems to Implement Strategy. Journal of Management Accounting Research. v.18, n.1, p.21-53, 2006.

NETEMEYER, R. G.; BEARDEN, W. O.; SHARMA, S. Scaling procedures: issues and applications. Thousand Oaks: Sage Publications, 2003.

NOVAES, H. M. D. Pesquisa em, sobre e para os serviços de saúde: panorama internacional e questões para a pesquisa em saúde no Brasil. Caderno Saúde Pública, v.20 (Sup. 2), p.S147S173, 2004.

OTLEY, D. T. The contingency theory of management accounting: achievements and prognosis. Accounting, Organizations and Society. v.5, n.4, p.413-428, 1980.

OYADOMARI, J. C. T. Uso do sistema de controle gerencial e desempenho: um estudo em empresas brasileiras sob a ótica da VBR (Visão Baseada em Recursos). Tese (Doutorado) Faculdade de Economia, Administração e Contabilidade, Universidade de São Paulo (FEA/USP), São Paulo, 2008.

OYADOMARI, J. C. T. et al. Uso do sistema de controle gerencial e desempenho: um estudo em empresas brasileiras sob a perspectiva da Resources-Based View. REAd - Revista Eletrônica de Administração, v.17, n.2, p.298-329, 2011. 
OYADOMARI, J. C. T. et al. Relacionamentos entre controle gerencial, aprendizagem e decisões. In: CONGRESSO USP DE CONTROLADORIA E CONTABILIDADE, 10., 2010, São Paulo (SP). Anais... São Paulo: USP, 2010.

PATTON, M. Q. Qualitative evaluation and research methods. 2. ed. Newbury Park: Sage Publications, 1990.

PERIN, M. G. A relação entre orientação para mercado, aprendizagem organizacional, e performance. Tese (Doutorado em Administração) - Programa de Pós-Graduação em Administração da Universidade Federal do Rio Grande do Sul (UFRGS), Porto Alegre, 2001.

PERIN, M. G. et al. Processo de aprendizagem organizacional e desempenho empresarial: o caso da indústria eletroeletrônica no Brasil. RAE-eletrônica, v.5, n.2, art.14, 2006.

PRICE WATERHOUSE. Fusões e aquisições no Brasil. 2011. Disponível em:

$<$ http://gvcepe.com/site/wp-content/uploads/2012/02/PWC_relatorio-mea-dezembro-20111.pdf $>$. Acesso em: 26 mar. 2013.

PROCHNICK, V.; DIAS, L.N.; CARVALHO, F.M. A utilização do balanced scorecard em hospitais: o caso do Hospital Nove de Julho. In: CONGRESSO BRASILEIRO DE CUSTOS, 12., 2005, São Paulo. Anais... São Paulo, 2005.

RINGLE, C.M.; WENDE, S.; WILL, A. SmartPLS 2.0 M3 (beta). Germany: University of Hamburg, 2005. Disponível em: 〈http://www.smartpls.de〉. Acesso em: 26 mar. 2013.

SALU. E. Aumento de faturamento do InCor: como se deu. 2012. Disponível em: <http://saudeweb.com.br/30455/veja-como-aumentar-o-faturamento-parte-1/>. Acesso em: 26 mar. 2013.

SEIDMAN, I. E. Interviewing as qualitative research: a guide for researchers in education and the social sciences. New York: Teachers College, Columbia University, 1991.

SIMONS, R. Levers of control: how managers use innovative control systems to drive strategic renewal. Boston: Harvard Business School Publishing, 1995.

Performance measurement and control systems for implementing strategy. New Jersey: Prentice Hall, 2000.

SMITH, D.; LANGFIELD-SMITH, K. Structural equation modeling in management accounting research: critical analysis and opportunities. Journal of Accounting Literature, v.23, p.49-86, 2004.

TANAKA, O. Y., TAMAKI, E. M. O papel da avaliação para a tomada de decisão na gestão de serviços de saúde. Ciência \& Saúde Coletiva, v.17, n.4, p.821-828, 2012.

TENENHAUS, M. et al. PLS path modelling. Computational statistics and data analysis, v.48, p.159-205, 2005.

TIPPINS, J. J.; SOHI, R. S. It competence and firm performance: is organizational learning a missing link? Strategic Management Journal, v.24, p.745-761, 2003. 
VERA, D.; CROSSAN, M. Organizational learning and knowledge management: toward an integrative framework. In: EASTERBT-SMITH, M.; LYLES, M. A. (Eds.). The Blackwell handbook of organizational learning and knowledge management. Blackwell (UK): Wiley, 2003, p.122-141.

WETZELS, M. et al. Using PLS path modeling for assessing hierarchical construct models: guidelines and empirical illustration. MIS Quarterly, v.33, n.1, p.177-195, 2009.

WIDENER, S. K. An empirical analysis of the levers of control framework. Accounting, Organizations and Society, v.32, n.7-8, p.757-788, 2007.

YIN, R. K. Estudo de caso: planejamento e métodos. 2. ed. Porto Alegre: Bookman, 2001.

ZANARDO, M.L.A.M. Gerenciamento das operações hospitalares como vantagem competitiva. 2004. Tese (Doutorado em Administração) - Programa de Pós-Graduação em Administração da Escola de Administração de Empresas de São Paulo (FGV), São Paulo, 2004.

\section{APPENDIX: QUESTIONNAIRE AND DESCRIPTIVE STATISTICS}

Indicate the degree to which managers and senior executives use management controls to carry out the activities described. Mark 1 (never used) to 5 (always used

Descriptive analyses of the variables - construct: diagnostic use

\begin{tabular}{|c|c|c|c|c|}
\hline & Description of the variables & Mean & $\begin{array}{l}\text { Standard } \\
\text { deviation }\end{array}$ & $\begin{array}{l}\text { Factor } \\
\text { loading }\end{array}$ \\
\hline DU 1 & 1. Monitoring the attainment of targets & 3.73 & 1.30 & 0.877 \\
\hline DU 2 & 2. Forecasting the most likely results & 3.46 & 1.25 & 0.882 \\
\hline DU 3 & $\begin{array}{l}\text { 3. Making small adjustments after comparing targets versus } \\
\text { results achieved }\end{array}$ & 3.56 & 1.15 & 0.874 \\
\hline DU 4 & $\begin{array}{l}\text { 4. Analyzing only significant variations between the planned and } \\
\text { realized budget }\end{array}$ & 3.48 & 1.13 & $(*)$ \\
\hline
\end{tabular}

Source: Research data.

Note: The factor loadings were obtained by PLS-PM and are significant at $1 \%$.

Legend: $(*)$ : Item removed from the model for having low factor loading.

Descriptive analyses of the variables - construct: interactive use

\begin{tabular}{|c|c|c|c|c|}
\hline & Description of the variables & Mean & $\begin{array}{l}\text { Standard } \\
\text { deviation }\end{array}$ & $\begin{array}{l}\text { Factor } \\
\text { loading }\end{array}$ \\
\hline UI 1 & 5. Revising the main targets & 3.65 & 1.21 & $(*)$ \\
\hline UI 2 & $\begin{array}{l}\text { 6. Discussing opportunities for improvement with superiors, } \\
\text { subordinates and peers }\end{array}$ & 3.60 & 1.28 & 0.846 \\
\hline UI 3 & 7. Formulating new action plans & 3.79 & 1.07 & 0.901 \\
\hline UI 4 & 8. Focusing on critical questions to the organization's success & 3.69 & 1.04 & 0.749 \\
\hline UI 5 & $\begin{array}{l}\text { 9. Unifying the organization's vision about the problems that } \\
\text { affect its performance }\end{array}$ & 3.40 & 1.20 & 0.854 \\
\hline
\end{tabular}




\begin{tabular}{c|l|c|c|c} 
UI 6 & 10. Creating a common language to all managers and executives & 3.38 & 1.16 & 0.871 \\
UI 7 & 11. Developing new strategies & 3.52 & 1.13 & 0.801 \\
\hline
\end{tabular}

Source: Research data.

Note: The factor loadings were obtained by PLS-PM and are significant at $1 \%$.

Legend: $(*)$ : Item removed from the model for having low factor loading.

Question: Analyze the statements below and indicate the degree to which they describe your organization, from 1 ("totally disagree") to 5 (totally agree).

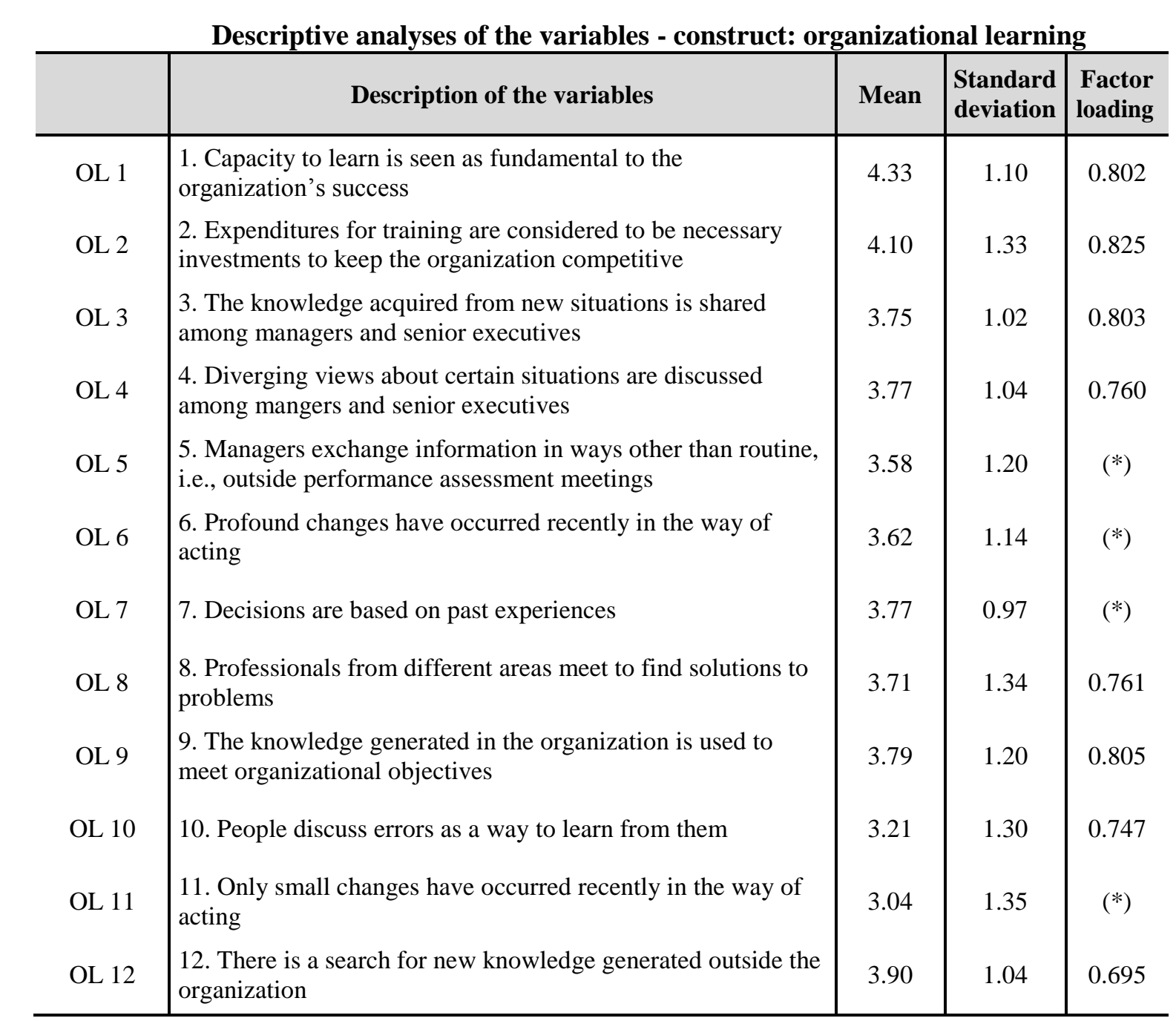

Source: Research data.

Note: The factor loadings were obtained by PLS-PM and are significant at $1 \%$.

Legend: $(*)$ : Items removed from the model for having low factor loadings. 
Question: If the decisions below were made in the past two years, indicate their degree of influence on the financial performance, from 1 (little influence) to 5 (great influence). Use N/A (not applicable) if the decision has not been made in that time frame.

Descriptive analyses of the variables - construct: management decisions

\begin{tabular}{|c|c|c|c|c|}
\hline & Description of the variables & Mean & $\begin{array}{l}\text { Standard } \\
\text { deviation }\end{array}$ & $\begin{array}{l}\text { Factor } \\
\text { loading }\end{array}$ \\
\hline & Decisions - Financial & & & \\
\hline DE 3 & 3. Focus on actions to reduce nonpayment & 3.33 & 1.52 & 0.820 \\
\hline DE 4 & 4. Negotiation of payment with suppliers & 3.83 & 1.29 & 0.868 \\
\hline \multirow[t]{2}{*}{ DE 5} & 5. Decisions on bank debt & 3.02 & 1.74 & 0.826 \\
\hline & Decisions - Costs \& Processes & & & \\
\hline DE 6 & 6. Improvement of margins and results. & 3.71 & 1.20 & 0.805 \\
\hline DE 7 & 7. Changes in cost calculations & 2.88 & 1.67 & 0.725 \\
\hline DE 8 & 8. Changes in medical procedures & 2.79 & 1.60 & 0.825 \\
\hline $\begin{array}{l}\mathrm{DE} \\
12\end{array}$ & 12. Inventory policy decisions & 2.90 & 1.83 & 0.750 \\
\hline & Decisions - Relationship with clients & & & \\
\hline DE 1 & 1. Ending an agreement with a health plan operator & 2.10 & 1.68 & 0.767 \\
\hline DE 2 & 2. Alterations of prices & 3.06 & 1.56 & 0.747 \\
\hline DE 9 & 9. Ceasing to offer a service & 2.71 & 1.64 & $(*)$ \\
\hline $\begin{array}{l}\text { DE } \\
10\end{array}$ & 10. Substitution of a doctor with another who charges lower rates & 2.02 & 1.74 & 0.731 \\
\hline $\begin{array}{l}\mathrm{DE} \\
11\end{array}$ & 11. Outsourcing of services. & 2.65 & 1.60 & 0.821 \\
\hline
\end{tabular}

Source: Research data.

Note: The factor loadings were obtained by PLS-PM and are significant at $1 \%$. Legend: (*): Items removed from the model for having low factor loadings. 
Question: With respect to the performance indicators below, indicate the degree of attainment in relation to the targets established: 1 (much less than expected); 2 (a bit less than expected); 3 (as expected); 4(a bit more than expected); 5 (much more than expected). Indicate N/A if the indicator is not used in your organization.

Descriptive analyses of the variables - construct: performance

\begin{tabular}{|c|c|c|c|c|}
\hline & Description of the variables & Mean & $\begin{array}{l}\text { Standard } \\
\text { deviation }\end{array}$ & $\begin{array}{l}\text { Factor } \\
\text { loading }\end{array}$ \\
\hline & Economic Performance & & & \\
\hline P 1 & 1. Gross revenue & 2.69 & 1.62 & 0.882 \\
\hline P 2 & 2. Profit & 1.88 & 1.26 & 0.936 \\
\hline P 3 & 3. Return on investment & 1.88 & 1.39 & 0.911 \\
\hline & Non-Monetary Performance & & & \\
\hline P 4 & 4. Client satisfaction & 3.56 & 1.16 & 0.860 \\
\hline P 5 & 5. Process quality indicators & 2.97 & 1.40 & 0.930 \\
\hline P 6 & 6. Overall performance & 3.09 & 1.20 & 0.902 \\
\hline
\end{tabular}

Source: Research data.

Note: The factor loadings were obtained by PLS-PM and are significant at $1 \%$. 